NOTE

\title{
Occurrence of Edwardsiella tarda in wild European eels Anguilla anguilla from Mediterranean Spain
}

\author{
Elena Alcaide, Sonia Herraiz, Consuelo Esteve* \\ Departamento de Microbiología y Ecología, Universidad de Valencia, 46100 Burjassot, Valencia, Spain
}

\begin{abstract}
Pure cultures of Edwarsiella tarda were isolated from body ulcers and internal organs of wild European eels caught in a Mediterranean freshwater coastal lagoon (Albufera Lake, Valencia, Spain) over a 1 yr period. Overall, the E. tarda isolation rate from wild eels was $9 \%$, but this increased to $22.8 \%$ in diseased individuals. All 22 E. tarda isolates belonged to the 'wild-type' biogroup of the species and were virulent for eels (lethal dose that kills $50 \%$ of exposed individuals [LD ${ }_{50}$ dose]: $10^{4.85}$ to $10^{6.83} \mathrm{CFU}$ ind..$^{-1}$ ), and therefore represented the aetiological agent of the haemorrhagic disease observed in wild European eels. The E. tarda isolates and E. tarda CECT $894^{\mathrm{T}}$ type strain were biochemically and serologically related and resistant to macrolides, antifolates, and glycopeptides, but only the isolates from wild eels were resistant to clindamicyn. This study is the first description of edwardsiellosis in a wild European eel population, and alerts us to the presence of E. tarda in natural wetland environments in Mediterranean Europe.
\end{abstract}

KEY WORDS: Edwardsiella tarda $\cdot$ Wild European eels $\cdot$ Fish pathogen

Resale or republication not permitted without written consent of the publisher

\section{INTRODUCTION}

Edwardsiella tarda is the causative agent of edwardsiellosis, a common epizootic disease of cultured (Meyer \& Bullock 1973, Wakabayashi \& Egusa 1973, Kusuda \& Kawai 1998) and wild fish species (FrancisFloyd et al. 1993, Baya et al. 1997). It has been reported in tropical and subtropical areas of Africa, America, Asia and Australia. Moreover, E. tarda is recognized as a serious human pathogen that may cause gastrointestinal and extraintestinal infections (Janda \& Abbott 1993). Risk factors associated with E. tarda infections in humans include exposure to aquatic environments or exotic animals, pre-existing hepatobiliary diseases, and eating habits (Vandepitte et al. 1983, Mowbray et al. 2003, Wang et al. 2005).

To date, Edwardsiella tarda isolations in Europe have been rare, the only reports being those related to its recovery from ornamental tropical fish and cultured turbot (Vladik et al. 1983, Nougayrede et al. 1994). In Europe, E. tarda has not been associated with bacterial infections affecting the European eel Anguilla anguilla (Biosca et al. 1991, Esteve et al. 1993, Høi et al. 1998), even though intensive eel farming is widely practised to satisfy market demands and supplement declining wild eel stocks. The occurrence of edwardsiellosis in eel has so far been limited to the Japanese and Taiwanese aquaculture industry (Wakabayashi \& Egusa 1973, Chang \& Liu 2002). In fact, the first isolation of the bacterium was in Japan, where Hoshina (1962) named the organism Paracolobactrum anguillimortiferum. The name E. tarda, which is now accepted world-wide, was proposed by Ewing et al. (1965). Based on phenotypic characteristics, E. tarda isolates were grouped into 3 different biogroups (Ewing et al. 1965, Grimont et al. 1980, Walton et al. 1993): (1) sucrose (suc)-, mannitol (manol)-, and -arabinose (ara)negative, and hydrogen sulphide $\left(\mathrm{H}_{2} \mathrm{~S}\right)$ positive 'wild- 
type' strains associated with humans and fish infections; (2) suc $^{+}$, manol $^{+}$, ara ${ }^{+}$, and $\mathrm{H}_{2} \mathrm{~S}^{-}$Biogroup 1 strains isolated from diseased zoo animals (reptiles and birds); and (3) $\mathrm{suc}^{+}, \mathrm{manol}^{-}$, $\mathrm{ara}^{+}$, and $\mathrm{H}_{2} \mathrm{~S}^{-}$Biogroup 2 strains, which have only been isolated from humans.

The present study is the first to describe the occurrence of Edwardsiella tarda 'wild-type' strains in wild European eels. Infected eels were caught in a Mediterranean freshwater coastal lagoon (Albufera Lake, Valencia, Spain). We tested our isolates for their virulence for eels and for their microbial susceptibilities. In addition, their serological relationships were studied and compared with the E. tarda type strain.

\section{MATERIALS AND METHODS}

Sample collection and microbiological analysis. Over the period of 1 yr (October 2003 to December 2004), the wild European eel Anguilla anguilla collected from Albufera Lake (Valencia, Spain) was studied on 10 occasions. Samples were mainly collected in autumn and winter, because eel (silver and yellow states) capture rates were highest during these seasons. Albufera Lake is a freshwater lagoon located $12 \mathrm{~km}$ south of Valencia city, close to the Mediterranean Sea, from which it is separated by a small littoral bar approximately $1 \mathrm{~km}$ wide. The lake is used for fishing and recreation; furthermore, lake water is used for agricultural purposes (rice cultivation). Eels are caught in the lagoon using traditional fishing procedures and are then briefly stocked in concrete ponds $(160 \times 80 \mathrm{~cm})$ supplied with well freshwater $(22$ to $24^{\circ} \mathrm{C}$ ) until sold. Edwardsiella tarda was not isolated from the well freshwater that supplied holding tanks, and the containers had only been used to hold European eels (data not shown).

A total of 88 eels were randomly chosen and analysed, including healthy eels as well as individuals showing pathological signs such as haemorrhagic fins, petechiae on the belly, and skin damage. Samples of skin, kidney and liver from both healthy and diseased animals were streaked onto tryptone soy agar plates (Oxoid) plus $1 \%$ (wt/vol) $\mathrm{NaCl}$ (TSA-1). All plates were incubated at $28^{\circ} \mathrm{C}$ for 24 to $48 \mathrm{~h}$. Colonies of each morphological type were picked and transferred to TSA-1 plates for purification. Bacterial isolates were routinely subjected to conventional tests as previously described (Esteve et al. 1993). API 20E strips (BioMérieux) were used to identify oxidative and fermentative bacteria (Edwardsiella spp. strains among the latter).

Phenotypic and serological characterization of Edwardsiella tarda isolates. E. tarda isolates recovered from wild European eels were further characterized using conventional plate and tube tests, which are currently used for E. tarda biotyping (Walton et al. 1993). Susceptibility of E. tarda isolates to antimicrobials currently used in chemotherapy and veterinary treatments was tested on Mueller-Hinton agar (Pronadisa) as previously described (Bauer et al. 1966). Type strain E. tarda CECT $849^{\mathrm{T}}$, which is a typical 'wild-type' strain of clinical origin (Ewing et al. 1965), was used in the phenotypic characterization for comparative purposes.

To examine the serological relationships among Edwardsiella tarda isolates recovered from different sampling occasions, we chose the isolate S16-10 to produce polyclonal antiserum in white female New Zealand rabbits. S16-10 was recovered from the only wild European eel suffering from edwardsiellosis, which was analyzed in Survey 1 . The antigen was formalin-killed cells, and the antiserum was generated by intravenous injection, as described previously (Sendra et al. 1997). Slide agglutination tests were conducted with this polyclonal antiserum on all E. tarda isolates as well as on strain E. tarda CECT $849^{\mathrm{T}}$ isolated from human faeces. Antiserum specificity was assessed using a strain of Escherichia coli CECT 515 as well as 5 Aeromonas hydrophila and Vibrio vulnificus isolates previously recovered from European eels as negative controls.

Virulence trials. Virulence of Edwardsiella tarda isolates was tested in juvenile European eels (elvers) by intraperitoneal (i.p.) injection. The fish (mean weight $6.2 \mathrm{~g}$ ) were housed in $20 \mathrm{l}$ aquariums supplied with freshwater and maintained at approximately $20^{\circ} \mathrm{C}$. Briefly, fish were anesthetized by immersion in a freshwater bath plus benzocaine at $2 \%$ (wt/vol) (Ross \& Ross 1984), and then 6 ind. per dose were injected with $0.1 \mathrm{ml}$ bacterial suspension containing $10^{7}$ to $10^{3} \mathrm{CFU}$ $\mathrm{ml}^{-1}$ in phosphate buffered saline (PBS). Sterile PBS was injected i.p. into fish serving as controls. Mortalities were recorded daily for $7 \mathrm{~d}$, and were only considered if pure cultures of injected E. tarda were recovered from dead fish. The $\mathrm{LD}_{50}$ was calculated according to Reed \& Müench (1938). The virulence of strain E. tarda CECT $849^{\mathrm{T}}$ was also assayed for comparative purposes.

\section{RESULTS}

\section{Phenotypic and serological properties of Edwardsiella tarda isolates}

Twenty-two Edwardsiella tarda isolates were obtained as pure cultures from necropsies of 8 wild European eels that showed haemorrhage at the base of the fins, petechial haemorrhage on the belly, enhanced mucus production and, in some cases, an ulcer in the 
opercula region. These 22 isolates showed API 20E codes that presumptively identified them as E. tarda (4 744 000, 4344000 and 4144 000). Isolates were biochemically characterized using conventional plate and tube tests (Table 1). Edwardsiella tarda isolates from wild eels showed biochemical homogeneity with each other and with type strain CECT $849^{\mathrm{T}}$, except under the conditions of Christensen's acetate test (Table 1). All E. tarda isolates as well as E. tarda CECT $894^{\mathrm{T}}$ produced $\mathrm{H}_{2} \mathrm{~S}$, but were non-reactive for acid production from L-arabinose, mannitol and sucrose, and so belonged to the 'wild-type' biogroup of this species (Table 1).

The sensitivity of Edwardsiella tarda isolates to various antimicrobials was compared with that of type strain CECT $849^{\mathrm{T}}$ (Table 2). Like the type strain, all E. tarda isolates were sensitive to ampicillin-sulbactam, cefotaxime, chloramphenicol, flumequine, nitrofurantoin, and oxolinic acid, but were resistant to vancomycin. Unlike the type strain, all but one of the iso-

Table 1. Edwardsiella tarda from Anguilla anguilla. Biochemical properties of E. tarda type strain CECT $849^{\mathrm{T}}$ and E. tarda isolates from the wild European eel $A$. anguilla. O/F: oxidative/fermentative; MR/VP: Methyl Red/Voges-Proskauer tests; SIM: Sulfide Indol Motility medium; +: all strains positive; -: all strains negative

\begin{tabular}{|c|c|c|}
\hline Test & $\begin{array}{c}\text { E. tarda } \\
\text { CECT } 849^{\mathrm{T}}\end{array}$ & $\begin{array}{l}\text { E. tarda isolates } \\
(\mathrm{n}=22)\end{array}$ \\
\hline Gram & - & - \\
\hline Oxidase & - & - \\
\hline Metabolism & $\mathrm{O} / \mathrm{F}$ & $\mathrm{O} / \mathrm{F}$ \\
\hline Motility & + & + \\
\hline Gas from glucose & + & + \\
\hline Indole & + & + \\
\hline MR/VP & $+/-$ & $+/-$ \\
\hline Christensen's citrate & + & + \\
\hline Christensen's acetate & - & $41 \%^{\mathrm{a}}$ \\
\hline Hydrogen sulfide (SIM) & + & + \\
\hline \multicolumn{3}{|l|}{ Acid from: } \\
\hline L-Arabinose & - & - \\
\hline Sucrose & - & - \\
\hline D-Melibiose & - & - \\
\hline Rhamnose & - & - \\
\hline L-Xylose & - & - \\
\hline Mannitol & - & - \\
\hline Sorbitol & - & - \\
\hline Salicin & - & - \\
\hline Maltose & + & + \\
\hline D-Mannose & + & + \\
\hline Glycerol & + & + \\
\hline \multirow[t]{3}{*}{ API $20 \mathrm{E}$ profiles at $37^{\circ} \mathrm{C}$} & 4744000 & $4744000(77 \%)^{b}$ \\
\hline & & $4144000(14 \%)$ \\
\hline & & $4344000(9 \%)$ \\
\hline \multicolumn{3}{|c|}{${ }^{\text {aPercentage of positive strains }}$} \\
\hline \multicolumn{3}{|c|}{${ }^{b}$ Percentage of strains exhibiting each API 20E code } \\
\hline
\end{tabular}

lates were resistant to clindamycin. Other differences between the isolates and type strain were minor. Among all E. tarda isolates, only isolate S23-12 was resistant to oxytetracycline and furazolidone.

All Edwardsiella tarda strains isolated from wild eels, as well as type strain E. tarda CECT $849^{\mathrm{T}}$, were strongly agglutinated by the rabbit polyclonal antiserum raised against formalin-killed cells of isolate S16-10. This agglutination reaction was similar regardless of the antigen (fresh whole cells or O antigen) used in tests (data not shown). No antigen derived from the Escherichia coli, Aeromonas hydrophila, or Vibrio vulnificus strains (the negative controls) was agglutinated by the anti-E. tarda S16-10 serum (data not shown).

\section{Occurrence of edwardsiellosis in wild European eels}

A total of 88 individuals were analysed from $10 \mathrm{col}-$ lections of wild European eel Anguilla anguilla from Albufera Lake during autumn and winter of 2003 and 2004. Among them, 35 individuals (39.8\%) were diseased fish, identified as such because they exhibited external pathological signs and yielded bacterial cultures from their internal organs. Specifically, wild European eels suffering from edwardsiellosis represented $9 \%$ (8 fish) of total individuals and $22.8 \%$ of total diseased fish (Table 3). Strains of Aeromonas spp., Vibrio vulnificus, and Pseudomonas sp. were recovered from other diseased fish (data not shown). Incidence of edwardsiellosis in this wild eel population was confirmed throughout the sampling period. The mortality rate owing to edwardsiellosis among captive eels was of $0 \%$, because all E. tarda-positive individuals recorded were alive. The morbidity rates observed were variable (from 0 to $28.6 \%$ ), with the maximum recorded in October 2003 (Table 3). These overall results suggest that holding conditions did not contribute to disease propagation in the captive eel population.

\section{Eel pathogenicity of Edwardsiella tarda strains}

The $\mathrm{LD}_{50}$ at Day 7 of the Edwardsiella tarda strains used in virulence trials are shown in Table 3. E. tarda isolates were virulent for eels, revealed by their $\mathrm{LD}_{50}$ values, which ranged from $7.4 \times 10^{4}$ to $6.6 \times 10^{6} \mathrm{CFU}$ ind. ${ }^{-1}$. External signs appeared $2 \mathrm{~d}$ after i.p. injection. Infected eels mainly exhibited haemorrhage and overproduction of mucus. Mortality was observed $3 \mathrm{~d}$ postchallenge and continued throughout the $7 \mathrm{~d}$ assay period. No mortalities were detected in eels injected with sterile PBS or with strain E. tarda CECT $849^{\mathrm{T}}$ (Table 3). 
Table 2. Edwardsiella tarda from Anguilla anguilla. Antimicrobial sensitivity of E. tarda isolates from the wild European eel A. anguilla compared with E. tarda type strain CECT $849^{\mathrm{T}}$. Most E. tarda isolates: isolates other than those named in the rest of this table. R: resistant; S: sensitive; I: intermediate; nd: not determined

\begin{tabular}{|lcccccccc|}
\hline Antimicrobial agent $(\mu \mathrm{g})$ & $\begin{array}{c}\text { Most E. tarda } \\
\text { isolates } \\
(\mathrm{n}=16)\end{array}$ & $\begin{array}{c}\text { E. tarda } \\
\text { S16-7 }\end{array}$ & $\begin{array}{c}\text { E. tarda } \\
\text { S23-11 }\end{array}$ & $\begin{array}{c}\text { E. tarda } \\
\text { S23-12 }\end{array}$ & $\begin{array}{c}\text { E. tarda } \\
\text { S33-29 }\end{array}$ & $\begin{array}{c}\text { E. tarda } \\
\text { S31-31 }\end{array}$ & $\begin{array}{c}\text { E. tarda } \\
\text { S88-177 }\end{array}$ & $\begin{array}{c}\text { E. tarda } \\
\text { CECT 849 }\end{array}$ \\
\hline Ampicillin-sulbactam (20) & $\mathrm{S}$ & $\mathrm{S}$ & $\mathrm{S}$ & $\mathrm{S}$ & $\mathrm{S}$ & $\mathrm{S}$ & $\mathrm{S}$ & $\mathrm{S}$ \\
Nitrofurantoin (30) & $\mathrm{S}$ & $\mathrm{S}$ & $\mathrm{S}$ & $\mathrm{S}$ & $\mathrm{S}$ & $\mathrm{S}$ & $\mathrm{S}$ & $\mathrm{S}$ \\
Cefotaxime (30) & $\mathrm{S}$ & $\mathrm{S}$ & $\mathrm{S}$ & $\mathrm{S}$ & $\mathrm{S}$ & $\mathrm{S}$ & $\mathrm{S}$ & $\mathrm{S}$ \\
Chloramphenicol (30) & $\mathrm{S}$ & $\mathrm{S}$ & $\mathrm{S}$ & $\mathrm{S}$ & $\mathrm{S}$ & $\mathrm{S}$ & $\mathrm{S}$ & $\mathrm{S}$ \\
Oxolinic acid (2) & $\mathrm{S}$ & $\mathrm{S}$ & $\mathrm{S}$ & $\mathrm{S}$ & $\mathrm{S}$ & $\mathrm{S}$ & $\mathrm{S}$ & $\mathrm{S}$ \\
Flumequine (30) & $\mathrm{S}$ & $\mathrm{S}$ & $\mathrm{S}$ & $\mathrm{S}$ & $\mathrm{S}$ & $\mathrm{S}$ & $\mathrm{S}$ & $\mathrm{S}$ \\
Vancomycin (30) & $\mathrm{R}$ & $\mathrm{R}$ & $\mathrm{R}$ & $\mathrm{R}$ & $\mathrm{R}$ & $\mathrm{R}$ & $\mathrm{R}$ & $\mathrm{R}$ \\
Sulphametoxazole-trimethoprim (25) & $\mathrm{R}$ & $\mathrm{R}$ & $\mathrm{R}$ & $\mathrm{R}$ & $\mathrm{S}$ & $\mathrm{R}$ & $\mathrm{nd}$ & $\mathrm{R}$ \\
Furazolidone (50) & $\mathrm{S}$ & $\mathrm{S}$ & $\mathrm{S}$ & $\mathrm{R}$ & $\mathrm{S}$ & $\mathrm{S}$ & $\mathrm{S}$ & $\mathrm{S}$ \\
Oxytetracyline (30) & $\mathrm{S}$ & $\mathrm{S}$ & $\mathrm{S}$ & $\mathrm{R}$ & $\mathrm{S}$ & $\mathrm{S}$ & $\mathrm{S}$ & $\mathrm{S}$ \\
Erythromycin (15) & $\mathrm{R}$ & $\mathrm{R}$ & $\mathrm{S}$ & $\mathrm{R}$ & $\mathrm{R}$ & $\mathrm{I}$ & $\mathrm{R}$ & $\mathrm{R}$ \\
Kanamycin (30) & $\mathrm{S}$ & $\mathrm{I}$ & $\mathrm{S}$ & $\mathrm{S}$ & $\mathrm{S}$ & $\mathrm{S}$ & $\mathrm{I}$ & $\mathrm{S}$ \\
Clindamicyn (2) & $\mathrm{R}$ & $\mathrm{S}$ & $\mathrm{R}$ & $\mathrm{R}$ & $\mathrm{R}$ & $\mathrm{R}$ & $\mathrm{R}$ & $\mathrm{S}$ \\
\hline
\end{tabular}

\section{DISCUSSION}

In the present study, we reported for the first time the presence of Edwardsiella tarda in wild European eels in Europe. Until now, E. tarda has never been associated with epizootics affecting wild or farmed eels in Europe (Biosca et al. 1991, Esteve et al. 1993, Høi et al. 1998). The infectivity experiments reported here clearly demonstrated that E. tarda was responsible for the disease signs occurring in some wild European eels from Albufera Lake (Valencia, Spain). The type strain of the species, which was isolated from human faeces, was not virulent for the European eel. It should be kept

Table 3. Edwardsiellosis in wild European eel Anguilla anguilla throughout the sampling period, and virulence properties of selected Edwardsiella tarda isolates and E. tarda type strain CECT $849^{\mathrm{T}}$. No. of diseased eels: total no. of individuals which yielded pure cultures from internal organs. Morbidity rate: (E. tarda-positive individuals/total collected eels) $\times 100 . \mathrm{LD}_{50}$ dose of E. tarda CECT $849^{\mathrm{T}}$ for European eel was $>4.0 \times 10^{7} \mathrm{CFU}$ ind $^{-1}$

\begin{tabular}{|c|c|c|c|c|}
\hline $\begin{array}{l}\text { Survey } \\
(\mathrm{mm} / \mathrm{dd} / \mathrm{yy})\end{array}$ & $\begin{array}{l}\text { Total collected } \\
\text { eels (total } \\
\text { diseased eels) }\end{array}$ & $\begin{array}{c}\text { No. of } \\
\text { diseased eels } \\
\text { (morbidity } \\
\text { rate) }\end{array}$ & $\begin{array}{l}\text { Selected } \\
\text { isolate }\end{array}$ & $\begin{array}{c}\text { Virulence for } \\
\text { European eel } \\
\text { LD }_{50}\left(\mathrm{CFU} \text { ind }^{-1}\right)\end{array}$ \\
\hline $1(10 / 08 / 03)$ & $6(1)$ & $1(16.7)$ & S16-10 & $7.6 \times 10^{5}$ \\
\hline $2(10 / 22 / 03)$ & $8(4)$ & $2(25)$ & $\begin{array}{l}\text { S21-13 } \\
\text { S23-12 }\end{array}$ & $\begin{array}{l}4.2 \times 10^{5} \\
3.0 \times 10^{5}\end{array}$ \\
\hline $3(10 / 30 / 03)$ & $7(2)$ & $2(28.6)$ & $\begin{array}{l}\text { S31-32 } \\
\text { S33-29 }\end{array}$ & $\begin{array}{l}1.4 \times 10^{6} \\
6.8 \times 10^{6}\end{array}$ \\
\hline $4(11 / 11 / 03)$ & $12(10)$ & $0(0)$ & - & - \\
\hline $5(11 / 25 / 03)$ & $10(7)$ & $0(0)$ & - & - \\
\hline $6(10 / 14 / 04)$ & $8(4)$ & $0(0)$ & - & - \\
\hline $7(10 / 26 / 04)$ & $10(3)$ & $1(10)$ & S77-141 & $7.5 \times 10^{4}$ \\
\hline $8(11 / 10 / 04)$ & $8(3)$ & $1(12.5)$ & S88-179 & $1.3 \times 10^{5}$ \\
\hline $9(12 / 01 / 04)$ & $9(1)$ & $1(11)$ & S99-184 & $2.2 \times 10^{5}$ \\
\hline $10(12 / 15 / 04)$ & $10(0)$ & $0(0)$ & - & - \\
\hline
\end{tabular}

in mind that E. tarda CECT $849^{\mathrm{T}}$ was originally described by Ewing et al. (1965) and has been subcultured since then in order to produce freeze-dried cultures by culture collection of microorganisms; therefore, its virulence could be attenuated.

Wild eel Edwardsiella tarda isolates and E. tarda CECT $894^{\mathrm{T}}$ were biochemically and serologically related: both belonged to the 'wild-type' biogroup of the species (Ewing et al. 1965, Grimont et al. 1980, Walton et al. 1993) and were strongly agglutinated by the polyclonal antiserum raised against E. tarda S16-10. No antigenic cross-reactivity was observed between E. tarda and antigens derived from isolates of Aeromonas hydrophila and Vibrio vulnificus. This contrasts with results reported by other authors (Sendra et al. 1997, Swain et al. 2003) who described antigenic sharing between A. hydrophila and E. tarda. Most E. tarda isolates showed resistance patterns to antimicrobials similar to that displayed by the E. tarda type strain, all of them being in accordance with the usual antibiotic susceptibilities described for Edwardsiella species (Stock \& Wiedemann 2001). Thus, our E. tarda isolates were resistant to macrolides, lincosamides, and glycopeptides, as well as to antifolates that currently inhibit $E$. tarda growth (Stock \& Wiedemann 2001). In addition, the isolate E. tarda S23-11 was resistant to oxytetracycline and furazolidone, and so could be a candidate for the search for the presence of R plasmids (Toranzo et al. 1983, Aoki \& Takahashi 1987). 
Edwardsiella tarda is recognized as a pathogen of cultured eels, as well as a natural inhabitant of fish, reptiles, and other cold-blooded animals, which occurs throughout the world with the exception of Europe. It is considered endemic to tropical countries, where high recovery rates of aquatic animals are common and where it also causes infections in humans and cultured fish (White et al. 1973, Kourany et al. 1977, Van Damme \& Vandepitte 1980, Francis-Floyd et al. 1993, Baya et al. 1997, Chang \& Liu 2002, Swain et al. 2003). In our study, the rates at which E. tarda was isolated from wild European eels were similar to those reported for freshwater fish in the tropics, which were in the range of 8 to $57 \%$ (Van Damme \& Vandepitte 1980, Faye et al. 1988). Because the presence of E. tarda in the wild European eel population of Albufera Lake was demonstrated for over a year, it was concluded that it may be present in the wetlands of Mediterranean Europe. Its presence in such locations poses potential hazards for the aquaculture industry.

Acknowledgements. The present study was supported by Project CGL2004-02009/BOS from the Spanish Ministry of Education and Science. We thank 'Cofradía de Pescadores del Palmar' for supplying eels.

\section{LITERATURE CITED}

Aoki Y, Takahashi A (1987) Class D tetracycline resistance determinants of $\mathrm{R}$ plasmids from the fish pathogens Aeromonas hydrophila, Edwardsiella tarda, and Pasteurella piscicida. Antimicrob Agents Chemother 31:1278-1280

Bauer AW, Kirby WM, Sherris JC, Turck M (1966) Antibiotic susceptibility testing by a standardized single disk method. Am J Clin Pathol 45:493-496

Baya AM, Romalde JL, Green DE, Navarro RB, Evans J, May EB, Toranzo AE (1997) Edwardsiellosis in wild striped bass from the Chesapeake Bay. J Wildl Dis 33:517-525

Biosca EG, Amaro C, Esteve C, Alcaide E, Garay E (1991) First record of Vibrio vulnificus biotype 2 from diseased European eel, Anguilla anguilla L. J Fish Dis 14:103-109

Chang CI, Liu WY (2002) An evaluation of two probiotic bacterial strains, Enterococcus faecium SF68 and Bacillus toyoi, for reducing edwardsiellosis in cultured European eel, Anguilla anguilla L. J Fish Dis 25:311-315

Esteve C, Biosca EG, Amaro C (1993) Virulence of Aeromonas hydrophila and some other bacteria isolated from European eels Anguilla anguilla reared in freshwater. Dis Aquat Org 16:15-20

Ewing WH, McWhorter AC, Escobar MR, Lubin AH (1965) Edwardsiella, a new genus of Enterobacteriaceae based on a new species, Edwardsiella tarda. Int Bull Bacteriol Nomencl Taxon 15:33-38

Faye H, Dosso M, Gershy-Damet GM, Kone P, Kouakou K (1988) First isolation of Edwardsiella tarda from fish in Abidjan: a possible source of human contamination. Bull Soc Pathol Exot Filiales 81:78-82

Francis-Floyd R, Reed P, Bolon B, Estes J, McKinney S (1993) An epizootic of Edwardsiella tarda in largemouth bass (Micropterus salmoides). J Wildl Dis 29:334-336
Grimont PAD, Grimont F, Richard C, Sakazaki R (1980) Edwardsiella hoshinae, a new species of Enterobacteriaceae. Curr Microbiol 4:347-351

Høi L, Dalsgaard I, DePaola A, Siebeling RJ, Dalsgaard A (1998) Heterogeneity among isolates of Vibrio vulnificus recovered from eels (Anguilla anguilla) in Denmark. Appl Environ Microbiol 64:4676-4682

Hoshina T (1962) On a new bacterium, Paracolobactrum anguillimortiferum sp. Bull Jpn Soc Sci Fish 28:162-164

Janda JM, Abbot SL (1993) Infections associated with the genus Edwardsiella: the role of Edwardsiella tarda in human disease. Clin Infect Dis 17:742-748

Kourany M, Vasquez MA, Saenz R (1977) Edwardsiellosis in man and animals in Panama: clinical and epidemiological characteristics. Am J Trop Med Hyg 26:1183-1190

Kusuda R, Kawai K (1998) Bacterial diseases of cultured marine fish in Japan. Fish Pathol 33:221-234

Meyer EP, Bullock GL (1973) Edwardsiella tarda, a new pathogen of channel catfish (Ictalurus punctatus). Appl Microbiol 25:155-156

Mowbray EE, Buck G, Humbaugh KE, Marshall GS (2003) Maternal colonization and neonatal sepsis caused by Edwardsiella tarda. Pediatrics 111:296-298

Nougayrede P, Vuillaume A, Vigneulle M, Faivre B, Luengo S, Delprat J (1994) First isolation of Edwardsiella tarda from diseased turbot (Scophthalmus maximus) reared in a sea farm in the Bay of Biscay. Bull Eur Assoc Fish Pathol 14:128-129

Reed MJ, Münch M (1938) A simple method for estimating fifty percent endpoints. Am J Hyg 27:493-497

Ross LG, Ross B (1984) Anesthetic and sedative techniques for fish. Brown, Son \& Ferguson, Glasgow

Sendra RM, Esteve C, Alcaide E (1997) Enzyme-linked immunosorbent assay for detection of Aeromonas hydrophila serogroup O:19. FEMS Microbiol Lett 157:123-129

Stock I, Wiedemann B (2001) Natural antibiotic susceptibility of Edwardsiella tarda, E. ictaluri and E. hoshinae. Antimicrob Agents Chemother 45:2245-2255

Swain P, Nayak SK, Sku A, Meher PK, Mishra BK (2003) High antigenic cross-reaction among the bacterial species responsible for diseases of cultured freshwater fishes and strategies to overcome it for specific serodiagnosis. Comp Immun Microbiol Infect Dis 26:199-211

Toranzo AE, Barja JL, Colwell RR, Hetrick FM (1983) Characterization of plasmids in bacterial fish pathogens. Infect Immun 39:184-192

Van Damme LR, Vandepitte J (1980) Frequent isolation of Edwardsiella tarda and Plesiomonas shigelloides from healthy Zairese freshwater fish: a possible source of sporadic diarrhoea in the tropics. Appl Environ Microbiol 39:475-479

Vandepitte J, Lemmens P, de Swert L (1983) Human edwardsiellosis traced to ornamental fish. J Clin Microbiol 17:156-167

Vladik P, Prouza A, Vitovec J (1983) Finding of the bacterial species Edwardsiella tarda in the aquarium fish Betta splendens. Vet Med 28:249-254

Wakabayashi H, Egusa S (1973) Edwardsiella tarda (Paracolobactrum anguillimortiferum) associated with pondcultured eel diseases. Bull Jpn Soc Sci Fish 39:931-936

Walton DT, Abbot SL, Janda JM (1993) Sucrose-positive Edwardsiella tarda mimicking a biogroup 1 strain isolated from a patient with cholelithiasis. J Clin Microbiol 31:155-156

Wang IK, Kuo HL, Chen YM, Lin CL, Chang HY, Chuang FR, Lee MH (2005) Extraintestinal manifestations of Edwardsiella tarda infection. Int J Clin Pract 59:917-921

White FH, Simpson CF, Williams LE Jr (1973) Isolation of Edwardsiella tarda from aquatic animal species and surface waters in Florida. J Wildl Dis 9:204-208

Submitted: February 24, 2006; Accepted: September 19, 2006

Proofs received from author(s): November 6, 2006 